\title{
Salinas: Interstices of the Urban, Cultural and Political Processes in Mediterranean Ecologies
}

\author{
Ana Morcillo Pallares
}

\begin{abstract}
Salinas, or Mediterranean coastal salt marshes, are priceless ecological wetlands, resilient spaces along the coast that have survived over time and hold incalculable cultural, historical, and ethnographic values associated with them. Today, artisanal sea salt production is no longer a profitable business, and in many cases, these spaces become a no-man's-land in-between nature and city, falling victims to pressures of changing land uses and the unsustainable urban growth of the Mediterranean coastal tourism. However, the process of change and abandonment of these former production landscapes presents an opportunity to promote new formulas for spatial tactics, public use and new sustainable futures. A liminal condition full of spatial and formal assets that opens the rising potential of the local economy and the right of the salina's active exploitation, interaction and identification.
\end{abstract}

Keywords: landscape reuse, liminal space, resilient edge, salinas, salt works

For more than three thousand years, salt has been intrinsically connected to the commercial activities and socio-politics of the Phoenician, Greco-Roman, Judeo-Christian and Islamic cultures, and has made a considerable contribution to the progression of these civilizations. The salt works or salinas, where the salt is extracted from seawater through the process of evaporation, have played a decisive role in the urban, cultural, ecological, socio-economic and political processes throughout the history of the southern Mediterranean region. The collection and commercialization of salt for the conservation of food was key in the financing of the modern European states through the taxes associated with this product. 
Its importance can also be seen in the etymological origins of the word "salary" which comes from the Latin word salaries, which means "of salt or pertaining to salt," and later on produced the noun salarium, "ration of salt," or "salary." "This singular symbiosis of man and landscape has represented an environmentally respectful process based on the use of traditional techniques, local materials and renewable energies.

However, today the artisanal production of sea salt is no longer a profitable business due to the rapid extraction of this mineral from land salt mines. This shift in salt production has turned many of the traditional salt works into a no-man's-land, falling victims to pressures of changing land uses and the unsustainable urban growth of the Mediterranean coastal tourism. These landscapes, found at the edge between city and nature, continue to have a strong presence even though the majority of these once prosperous salt works have been transformed or abandoned. In addition to this, the raise in temperatures, due to global warming and the pollution from harmful agriculture practices, have placed these delicate ecological habitats and their fauna in a serious state of emergency. The current situation not only threatens ecological loss but also the loss of heritage and the loss and historical identity of the traditional salinero villages and their peoples. This disparate scenario of change and abandonment of these former production landscapes presents an opportunity to promote new formulas for spatial tactics, public use and new sustainable futures for the salinas. Recent investments in salt works along the coast of Spain are witness to new possibilities of life along these forgotten edges. The beginning of this shift from "production landscapes" to "landscapes of reuse" is feasible by the integration of new programs, natural elements and built structures that showcase the process of site transformation, adapting and overlaying new spaces that respond to the ever-changing needs of our cultural, economic, and political forces.

\section{SALTSCAPES AS RESILIENT EDGES}

The present research comprised two areas of study. First, a survey, through on-site research field documentation of salinas in a state of abandonment, in order to understand the causes that lead them to their status. Secondly, an exploration of the design and site implementation with new hybrid proposals, where new programs and salt works live harmoniously and take advantage of the ecosystem they provide.

On one hand, the state of abandonment of these spaces and rupture of the cultural-historical balance and ecology of the area is a direct result of the poor management due to the lack of investment and the low profitability of the artisanal collection of salt. The joint ownership of both local public and private investors allows an indeterminate future of the salinas as production landscapes which leads to slow decision making as can be seen in the unfortunate current conditions of the Marchamalo salina in Murcia, 


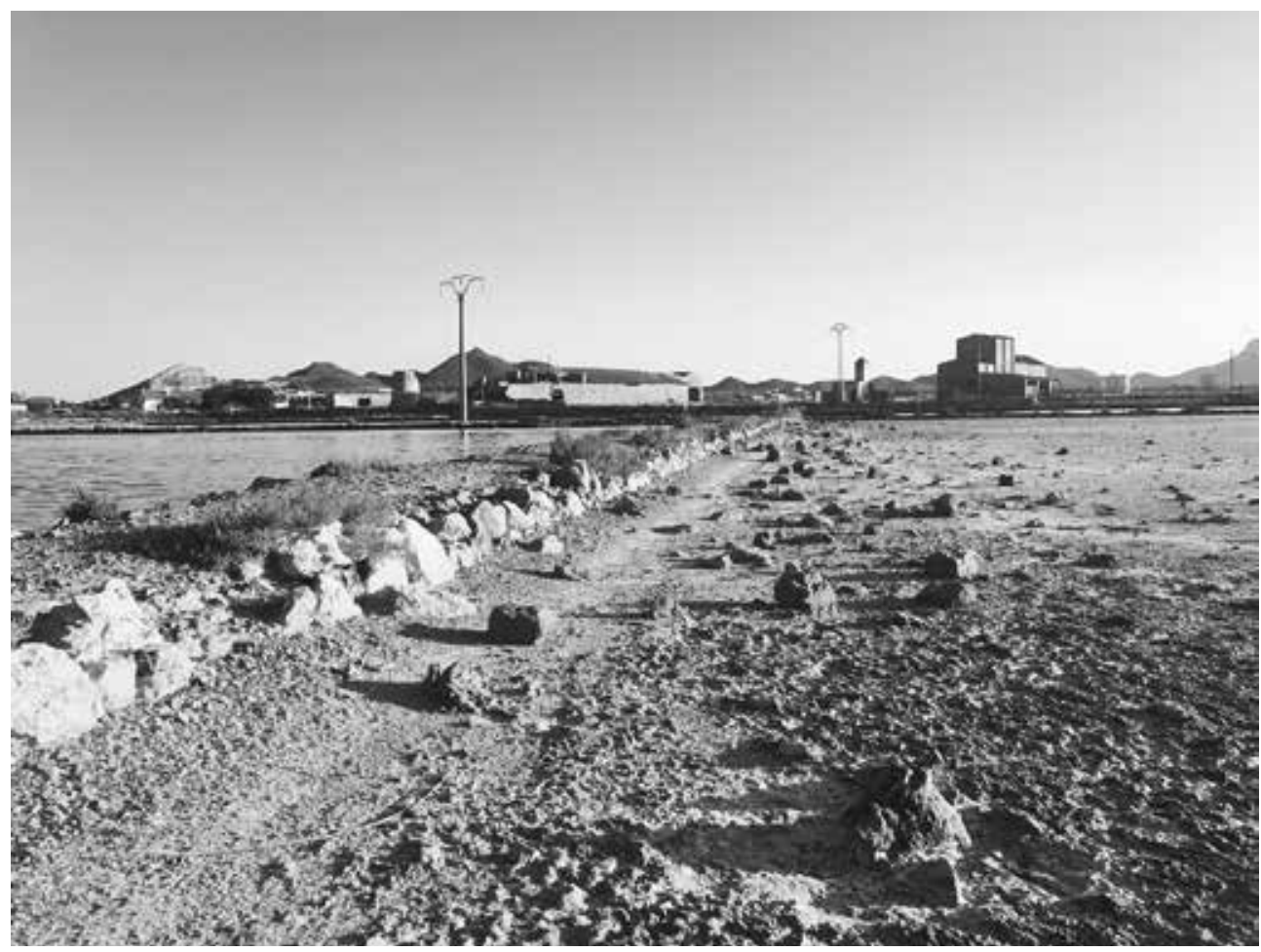

Figure 1. State of abandonment of the Marchamalo salina, Mar Menor, Murcia, Spain (2017).

Southeastern Spain (Fig. 1). Marchamalo represents a clear case of abandonment due to the lack of funding and political coordination, and the absence of new ideas. Local agents have not been able to find a solution to this resilient and centenary edge, despite its privileged location next to the Mar Menor salt lagoon. This unique area hosts an extremely important ecosystem for bird migration and part of the special protection plan as a Lugar de Importancia Comunitaria (LIC), ${ }^{2}$ as defined by the policies of the European Union. In other examples, where funding was not a problem and the embracing of new programs beyond salt production were introduced, the value of this resilient edge has been put under pressure.

This can be seen in the lamentable case of the relaxation park designed by the world-renowned architect Toyo Ito in 2000 in the Salinas de la Mata in Torrevieja. ${ }^{3}$ The project had the ambitious objective of becoming an international reference of health tourism that provided a plan for touristic regeneration within the natural salt lagoon through the construction of three helical pavilions and thirty-five ft. [10,6 m] tall man-made dunes (Fig. 2). However, the nefarious decision of the local administration to build a spa within a space of great ecological value of the natural park of the Salinas de la Mata was doomed to fail. Without a previous environmental impact study and the required permission by the national governmental entity for the protection of coastal areas, the project was stopped in 2006 and, until today, the first unfinished pavilion remains in a state of abandonment. In this case, the resilience of this edge did not occur through the 
promotion of new activities via the desired tourist exploitation. Instead, the preservation of the protected environment was guaranteed by means of an administrative sanction that upheld the quality and value of the ecological heritage over the quality of the architectural proposal and "innovative" programming. ${ }^{4}$

On the other hand, and until very recently, the economic interests associated with the collection of salt has had a relatively small impact on the surrounding context and is most likely why some of these coastal wetlands have been conserved. The progressive privatization of the salt works has been a sign of investment that these areas of exploitation have aroused. Groups of small landholders have functioned as an efficient maintenance network and, in many cases, they have prevented the desiccation as a result of the lack of presence and intermittent funding of local public agencies. The identification of socio-economic possibilities and natural preservation is one of the foundations of the most recent trends in the management of salt wetlands along the Mediterranean coast. Throughout the centuries, the traditional salina has been a sustainable model between man and nature. Its slow but progressive cultural adaptation has allowed its exploitation, as well as perfect habitat for species that find their optimum ecological system in it. In this sense, the primary objective is the focus on the sustainable value and maintenance that guarantee the public use of the salt boundary as an interchange between city and nature. To achieve this, it is necessary to go beyond the production landscape model by taking advantage of new mechanisms and diversification. Exploring initiatives like fishing, aquiculture, gastronomy, tourism and environmental education are crucial at the time of establishing a potential economic and ecological collaborative for the area. In 2000, the initiative for an influx of new activities was made possible as a result of the implementation of new policies for the protection and conservation of these areas as designated by the European plan "Nature Network 2000." 5 These projects have demonstrated the consolidation of a resilient salt boundary benefiting from a European ecological network that guarantees the conservation of its historic, cultural and natural biodiversity.

However, what was in principle a policy whose methodology applied strictly to the designation and protection of bird habitats, quickly expanded to include the recovery and protection of resources for tourism. These new tourism initiatives support a certain degree of potentiation and protection of the salinas in coastal areas beyond the summer season with the capability of generating new sustainable economies. Examples of these interventions include the archaeological recovery of the urban vestiges of the salt commerce in the archeological site of Baelo Claudia in Tarifa and the incorporation of new spatial programs in three traditional salinas: a recreational-health space in the salinas of Chiclana de la Frontera in the Natural Park of the Bay of Cádiz, a gastronomic space in the salt marshes of the Puerto de Santa Maria at the mouth of the river Guadalete, and the 


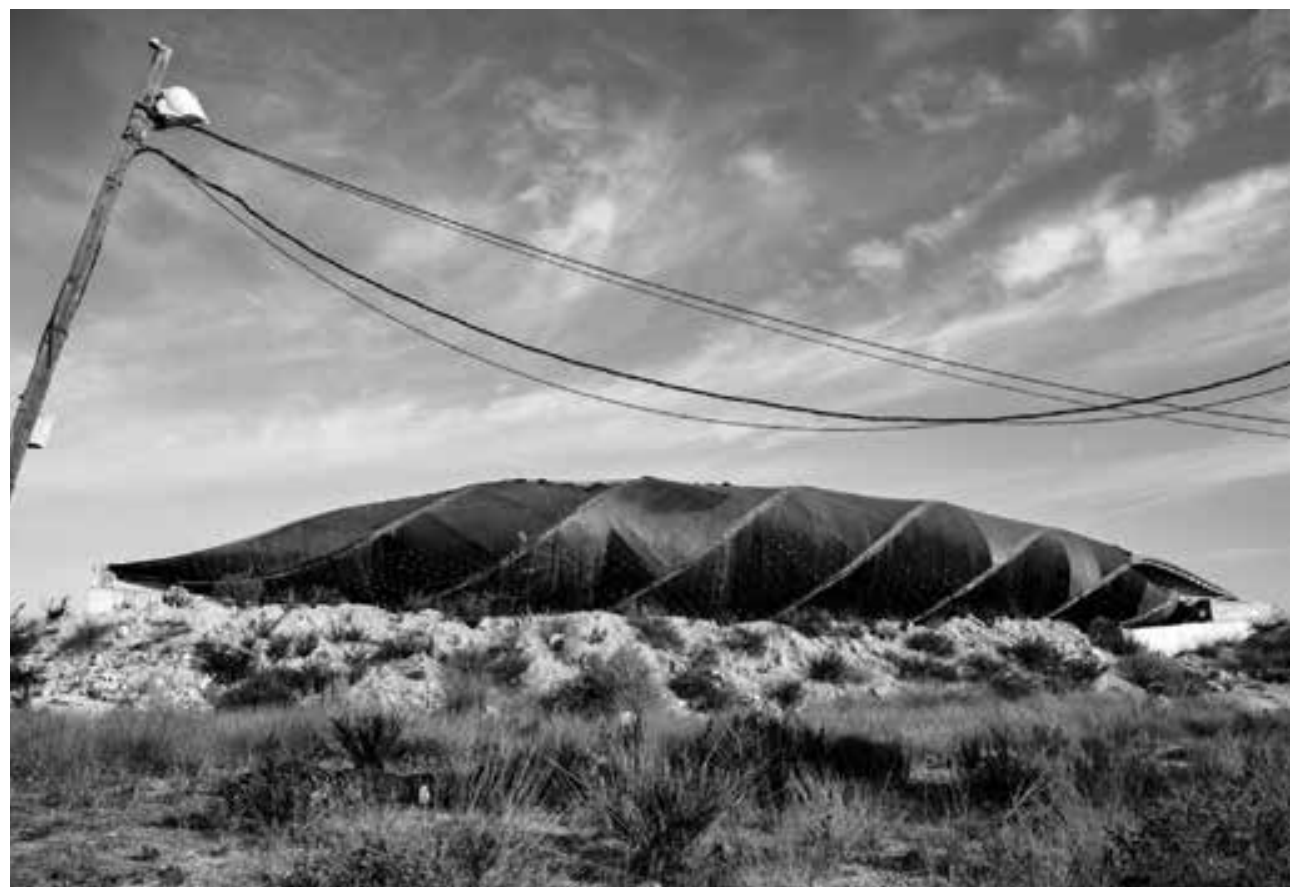

Figure 2. Unfinished Toyo Ito's pavilion at the natural park of the Salinas de la Mata, Torrevieja, Alicante, Spain (2014).

recuperation of the link between the industrial exploitation of salt and nature in the Protected Natural Area of Las Salinas and Arenales of San Pedro del Pinatar in the Region of Murcia.

\section{FOUR SPATIAL EXPERIENCES IN THE SALINERO'S RESILIENT EDGE}

These initial spatial experiences for the management, conservation and valorization of the boundary between the city, nature and the resilient edge of the salina are verified through their promising sensibility in respect to their programs, scale, size, attributes and temporality. These architectural proposals understand the singular needs of this environment at the time that they respect and take advantage of the hard and strange natural dimension of a "landscape that is extreme or of extremes." 6 The salinas, despite being environmental habitats with a high ecological value, are wetlands that require management by the hand of man to ensure the slow circulation of water. Their structure and compartmentalization allows for the careful control of water intake, isolation and distribution of levels of salinity that guarantee a high quality of salt as well as ideal conditions for the fauna that inhabits them. For this reason, the delicate balance between the salina and the new proposal needs to embrace this ambiguous state, a landscape that appears natural but carries with it a man-made Cartesian order in the form of divided salt crystalizing pools, walls and canals. These new programs must coexist in an environment divided between exuberant months during the nesting and breeding season of birds that feed on the microorganisms and fish that live in the clay silt of the salina. 


\section{Baelo Claudia: The Historical Edge and Salt Based Economy}

The spatial vestiges of the industrialization and commercialization of salt have their best historical example in the archaeological remains of the Roman city of Baelo Claudia. The municipality located in the Strait of Gibraltar, between the cove of Bologna and the sea, was founded at the end of the second century CE as a strategic location for maritime communication trade routes with North Africa. Tuna fishing and its subsequent conservation through salting established a flourishing industry until the decline of the municipality after an earthquake destroyed the city in the third century. The archeological remains are witnesses of the importance of the salt economy as seen through the remains of the factory buildings used for the preparation of the fish stored in wells between layers of salt (Fig. 3). ${ }^{7}$

The almost two thousand years of resilience of this historical-cultural boundary was made possible by its geographic isolation and the protection of the remains by wind swept sand dunes. Considered as the best preserved archeological site in Spain, its excavations began at the beginning of the twentieth century, but the Research Project for the Study of the Southern Regions Archeological Complexes was initiated only in 1999, and financed by the regional administration. In 2007, the internationally recognized architect Guillermo Vázquez Consuegra was charged with the task of developing a master plan for the archeological site as well as for the design of a visitor's center and entrance for the conserved remains.

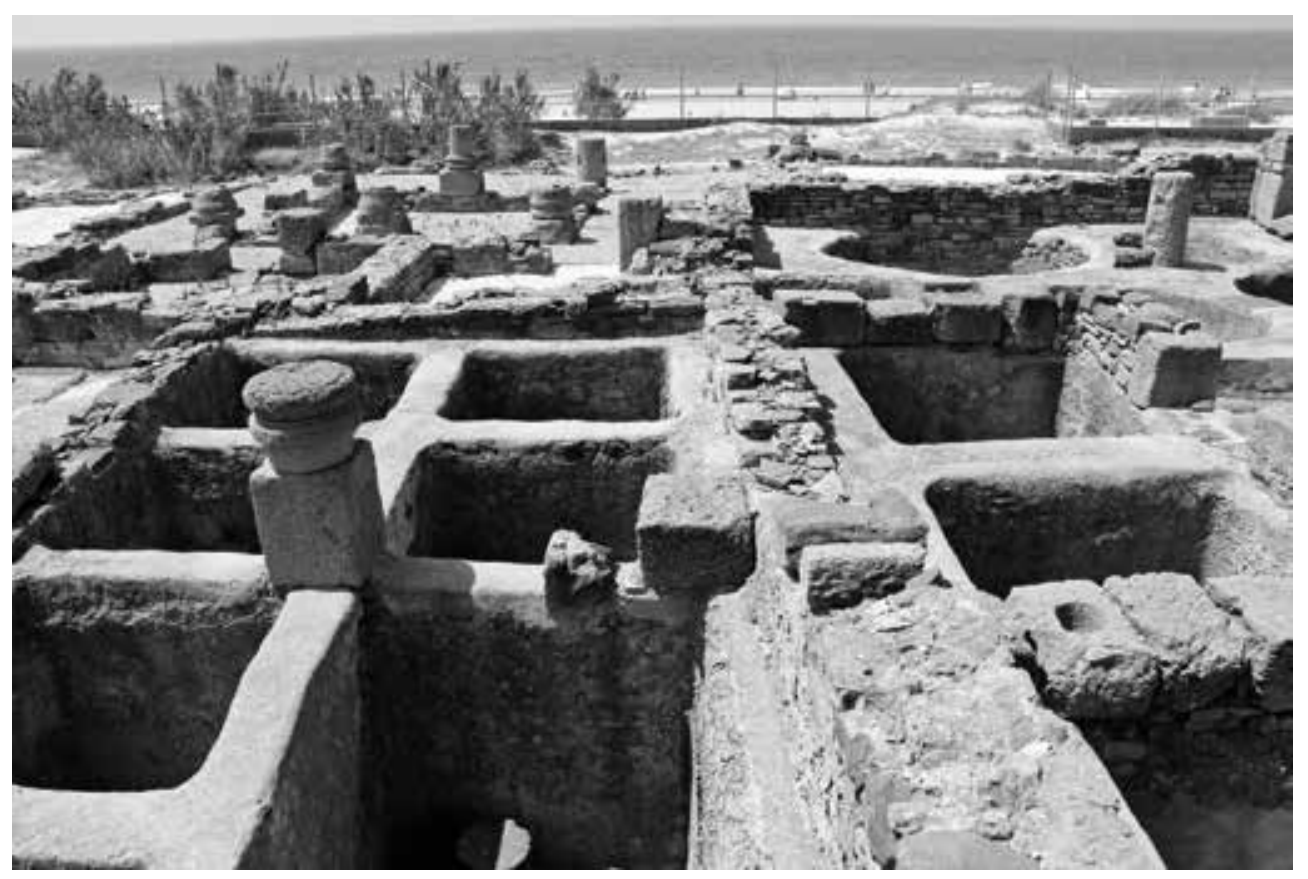

Figure 3. Salt wells at Baelo Claudia's archeological site, Tarifa, Cadiz, Spain (2017). 
His project reaffirms the resilience of the border condition of this remote salt and fishing population through the spatial adequacy of a punctual and massive spatial enclave, which is described by the architect as "a dense and Mediterranean architecture, closed and compact, able to interrogate itself through the characteristics of the place." ${ }^{8}$ And although today Baelo Claudia's activity is no longer directly related to its historical status as a commercial port and a large center for fish salting, its educational impact demonstrates an example of the resilience and survival of these first settlers thanks to the importance and the generation of wealth resulting from production of sea salt. ${ }^{9}$

\section{Chiclana de la Frontera: New Programming in the Salina}

The idea to introduce a new program in an artisanal salt work can be seen in the example of the first outdoors sustainable salt recreation spa in Europe located in Chiclana de la Frontera in the southwest coast of Spain. The proposal unites tradition and new activities as part of a private initiative that offers an alternative tourism through the connection of new proposals with old industries found in the area. ${ }^{10}$ The project, with an extremely low environmental impact, is located in the nature preserve of the Bahia de Cadiz, in the salina known as Santa Maria de Jesus. The intervention consists of a set of small demountable wooden platforms and pavilions that sit on top of the tajos, or pools of the salina at the final stage of the evaporation process. This is the moment when the water reaches its maximum level of salinity during the summer (Fig. 4).

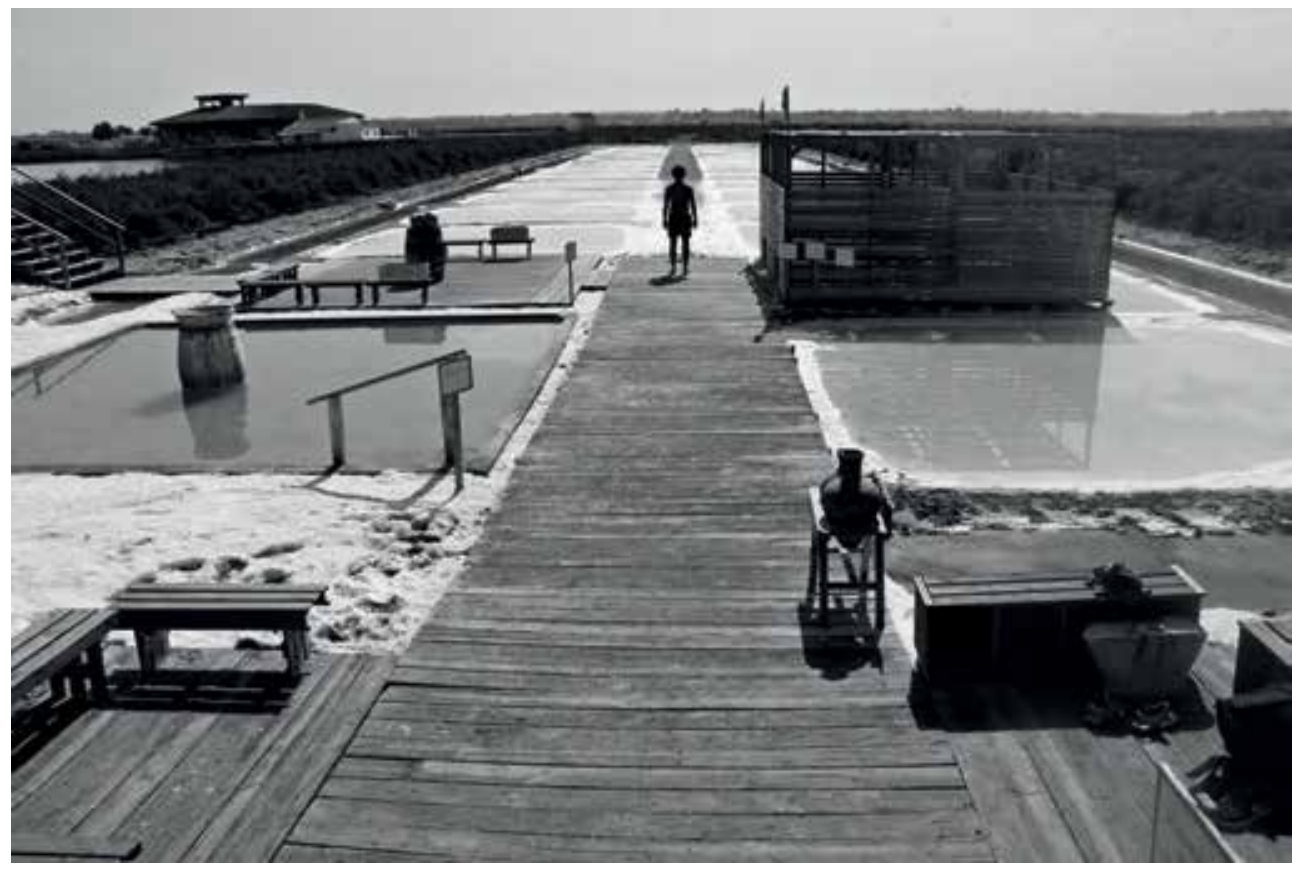

Figure 4. Outdoors salt recreation spa intervention, Chiclana de la Frontera, Cadiz, Spain (2017). 
Coinciding with the summer months, the open spa is an optimal example of ideal conservation, coordination of uses and maintenance. The appropriate adaptation of this resource allows for an optimal state in which the spa can take advantage of the beneficial health effects of the high concentration of minerals found in the salt water and the salina's muds. This water is rich in magnesium and sulfate as well as iron, zinc and iodine, which are very valuable for the skin's mineralization and elasticity. Another important element found in the spa treatment is a mud/clay that has a concentrated level of minerals and is extracted from the basin of the salinas where it has deposited over time. Once the mud has dried on the skin, it is washed off in one of the salt pools, thus completing the loop of the different phases and returning the minerals to the water of the salinas, with a maximum reuse of the waste generated in the process. Thanks to the maximum exploitation of the available resources and the minimal and reversible architectural intervention, Chiclana's spa represents another excellent example of salina, quite different from the case of Toyo Ito in Torrevieja. Chiclana's sustainable approach guarantees longevity and low maintenance of this artisanal salt work through a symbiotic relationship as a recreational-health installation.

\section{Tidal Mill in Puerto de Santa Maria: The Resilience of Patrimony}

The strategic location of the salinas within the coastal urban zones has produced interesting juxtapositions with other industries that have prospered in these areas. One of the vestiges of these industries are the so-called tidal mills. These mills, used to grind grain, harness the power of the tides as a source of clean and inexhaustible energy. In its heyday, these mills were a symbol of prosperity, but with the arrival of the industrial revolution they fell into disuse and only a few continued to function until the end of the nineteenth century. Today, the decisions for the planning, management and supervision of these mills are directly connected to the criteria and will of the public administration. As an example of this, the mill in Puerto de Santa Maria (Fig. 5), located in the important natural and commercial Bay of Cádiz, is an interesting case study, as it became one of the first of these structures to be loaned by the administration for its exploitation by a private enterprise. In this case, a gastronomic center and a restaurant.

This award-winning two Michelin star restaurant has proven to be more than an establishment for the preparation of high quality food. The chef and his team's desire is a better understanding of the salina known as Cano Mil, the wetland saltscape source adjacent to the tidal mill. This learning process is reflected on the restaurant's gastronomic laboratory, which is used to study the marine fauna and flora of the salina. Chef Angel Leon's fearless curiosity takes advantage of the water ecosystem for the cultivation and innovation of sea food. His practice is an inspiring example of cohabitation among new emerging disciplines within the disuse and abandoned city's edge. ${ }^{11}$ However, as always, these innovative interventions are never polemic free. The temporal transaction of thirty 


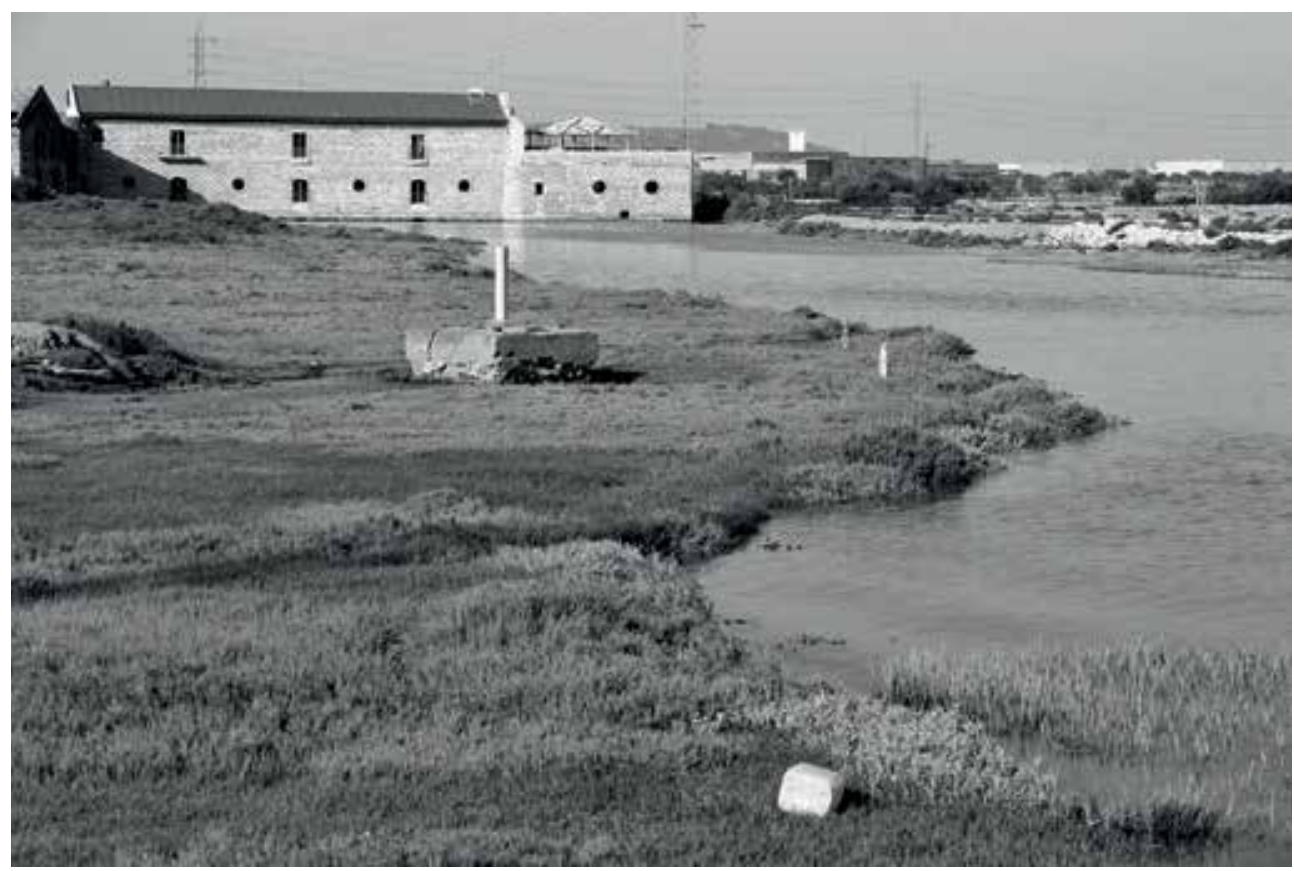

Figure 5. Tidal Mill's restoration Puerto de Santa Maria, Cadiz, Spain (2017).

years of the tidal mill into the hands of a private entity granted by the administration was received with criticism from local ecological nonprofit organizations. Ecologistas en Accion heavily opposed the privatization of the mill and reported that the historical and cultural landmark of the mill within its natural landscape should have not been transferred to a private entity but kept as a public one. ${ }^{12}$ In response to these concerns, one can also argue that the research carried out by the restaurant and its respectful relationship within its context allows for the initiation of new local approaches of economic revitalization at the edge of the salina. An initiative that reduces the possibility of neglect and guarantees an activity within the walls of an almost forgotten structure of the hydraulic and historic heritage.

\section{San Pedro del Pinatar: The Resilience of an Artificial Edge}

The three previous examples of resilient edges showcase experiences with a strong architectonic nature. However, the case of the Regional Park of the Salinas and Dunes of San Pedro del Pinatar in Murcia is an example of a man-made intervention that has been limited only to the restoration and preservation of a natural edge. In this example, the Salinas Marítimas Commonwealth was the private entity that exploited the salt works and needed an effective initiative to protect their investment from the advancement of the sand dunes located next to the salina. ${ }^{13}$ The final solution was a pine forest planted by the commonwealth in 1917. Today, this landscape is a haunting landscape of twisted and stoic pines that resists and protects the salt flats from the strong salt-laden winds of the Mediterranean. This edge offers an interesting scenario of shrub vegetation 
within the coastal dune areas for the enjoyment of visitors and locals (Fig. 6). In 2003, the winning proposal for the competition of the San Pedro linear park by the architect Arancha Muñoz Criado proposed the recovery of a large portion of the salina for recreation and leisure with the objective of making this almost invisible resilient landscape visible. The proposal focused on three aspects: the restoration of the characteristic reed and salt pools, the optimization of the existing water system and the recuperation of the salina ecosystem. ${ }^{14}$ Through the recuperation of the landscape, the main objective of the plan was to draw attention to the coastal forest as an example of one of the most resilient and singular edges between the salina and the Mediterranean sea. The nine pine trees planted in 1917 have multiplied through natural expansion to over six hundred trees today. This botanical jewel of the south Mediterranean region is considered the only wild dune forest that exists in the Region of Murcia together with very few other examples found on the rest of the Iberian Peninsula.

Even though the salt pools in the Regional Park of the Salinas and Dunes are still the most characteristic part of its landscape, the proposal by Muñoz Criado highlights, together with the coastal forest, other geomorphological elements of the area such as dunes, beaches and salt works (Fig. 7). ${ }^{15}$ The innovation of Muñoz Criado's plan is that her proposal does not intervene directly in the salt pools, but instead accentuates the peripheral elements as the true heirs of a multifunctional territory. This resilient periphery is key in the interworking between the artificial and natural landscape of the salina by defining a robust ecological and resilient edge for future social, cultural, economic and environmental progress.

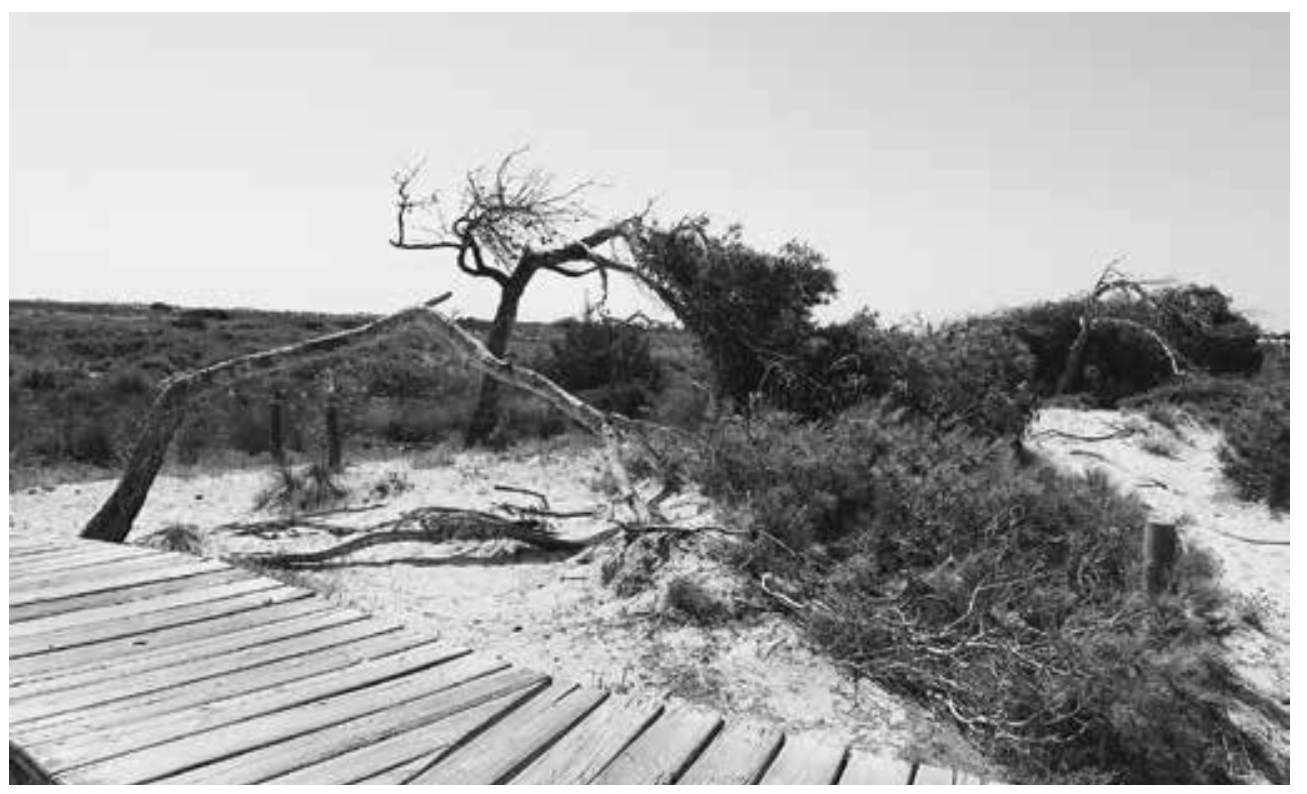

Figure 6. Three twisted individuals in the salt marsh forest, San Pedro del Pinatar, Murcia, Spain (2017). 

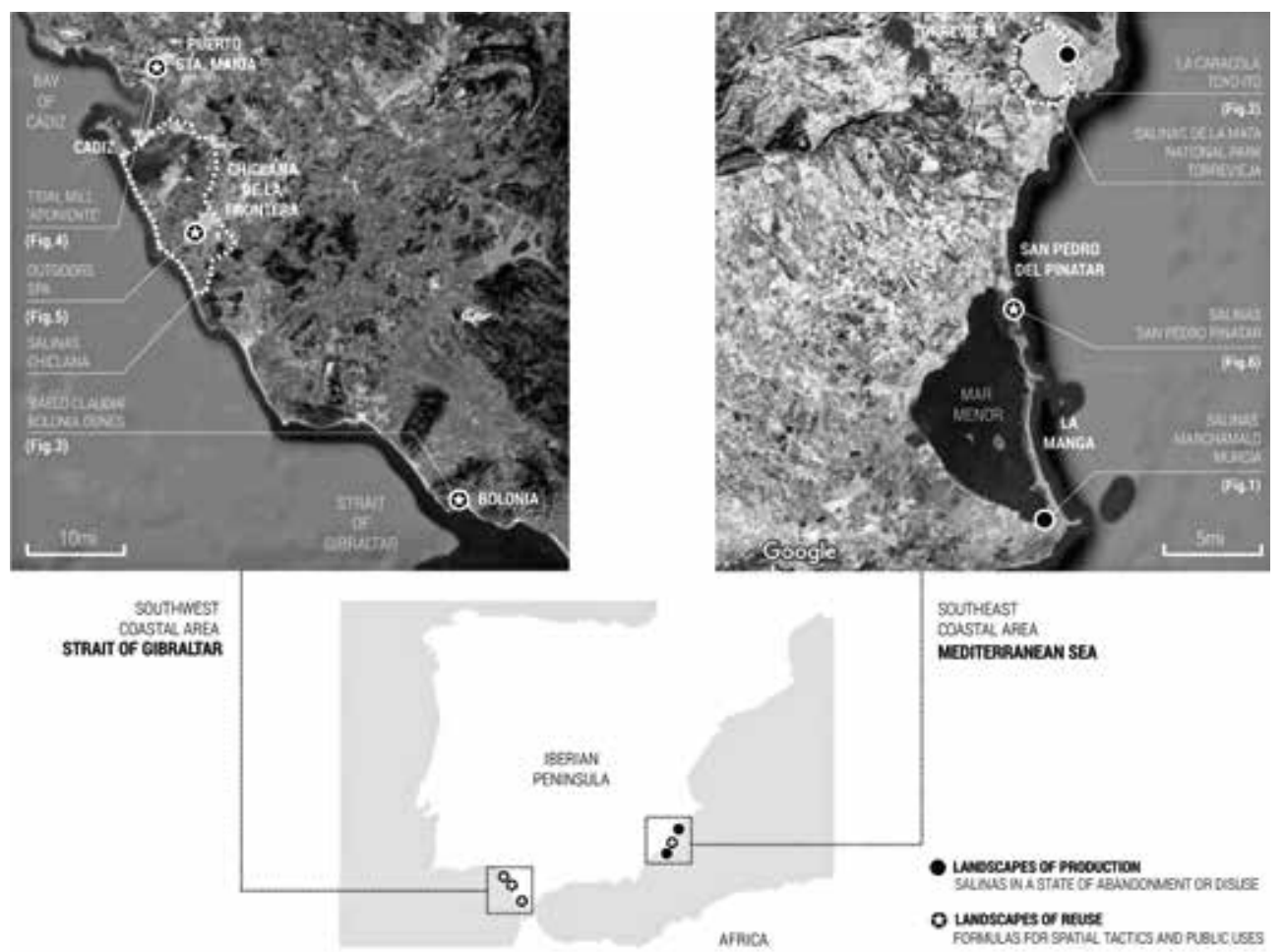

Figure 7. Salt works location.

\section{CONCLUSIONS}

The study of the four examples of resilient edges in between the contemporary urban, cultural and political processes illustrates the heightening and awareness of ways in which programmatic opportunities can position the remarkable historical, economic, scenic, sustainable and educational futures of the salinas. The uncertain economic situation of the salineros villages has created a demotivation in investing in them. This situation leads to a necessary paradigm shift for pioneering new initiatives and sustainable strategies of resilience and conservation of the salinas. They need to be perceived not as "problematic spaces," but, instead, "spaces for opportunity," as a way to combat their regrettable conditions of disuse, abandonment and degradation.

On one hand, the critical vision and negotiation among stakeholders is a key factor in developing and rethinking the liminal space in-between the ecological boundary, the salinas and the urban edge. The administration, private developers, planners, designers and citizens must develop an active posture in channeling the conflating demands to establish a balance between these ecological environments and the city. Actions like the administration's protection of an archeological site, a private entity initiating the first outdoors spa, an unstoppable chef's curiosity and a sustainable masterplan by a professional team are capable of achieving an active participation, identity and represent a commitment to the population with their cultural and historical heritage. A collective effort able to draw a 
consensus when it comes to acting by avoiding wrong decisions taken in the past, like the hasty political wishes of the project by Toyo Ito in Torrevieja or the lack of coordination of public entities and the subsequent state of abandonment of the salt works of Marchamalo in Murcia.

On the other hand, the very existence of the salinas poses a fundamental question for us as a way to understand the relationship between the human species and the environment. In this sense, the ambiguous condition of the salt flats as an artificial-natural laboratory is an example of the connection between man and nature that has maintained a resilient border between city and nature for centuries. Today, this edge presents an opportunity to develop the potential of different urban boundaries and their relationships with the environment for an urban population characterized today by its high heterogeneity and social fragmentation.

Finally, the depredation of planning, the growth of tourism, and the lack of protection of these natural environments open an intense debate about the future of the salinas, which have ceased to be spaces of opportunity for the collective. These factors mark a moment in which it is imperative to imagine other types of entrepreneurial opportunities committed to making these unique environments more effective ${ }^{16} \mathrm{New}$ ideas and prototypes for the design, production, development, maintenance and control of these spaces are essential in a society whose needs are constantly changing. The potential relationship of the salina within its urban and natural context requires a different type of sensibility and observation, or "an observer that is sensible and intelligent," 17 as Fernando Sánchez Royo, professor of Biology and Ecology at the University of Sevilla, explains. Just as reflected in the prose of the Spanish poet Rafael Alberti, where he invites us to find the emotional bond and the sense of belonging in-between us and this resilient edge, through his description of the immensity of the salinas: "the first whites that cleared my eyes were the salt of the salinas, the sails and the stretched wings of the gulls [...] I was a drawer and painter of beaches, salt landscapes, orchards and flower gardens." 18

\section{Notes}

1. Amparo María Ballester López, "Origen de la palabra salario," Lengua Española, Poesía y mi Gloriosa Santa Clara (blog), January 22, 2015, https://verbiclara.wordpress com/2015/01/22/origen-de-la-palabra-salario/.

2. "La asamblea pide un plan para recuperar y proteger las salinas de Marchamalo," La Opinión de Murcia, November 22, 2016.

3. "Parque de relajación de Torrevieja, Toyo Ito," Via Arquitectura, Summer 2007.

4. Rosa Biot, "Un edificio del arquitecto Toyo Ito languidece en Torrevieja," El País, April 1, 2010.

5. Ministerio de Agricultura y Pesca, Alimentación y Medio Ambiente. Gobierno de España, "Red Natura 2000," http://www.mapama.gob.es/es/biodiversidad/temas/espacios protegidos/red-natura-2000/default.aspx.

6. Fernando Sáncho Royo, "El paisaje de las salinas"; Alejandro Pérez Hurtado de 
Mendoza, "Las salinas andaluzas en la planificación y gestión integradas de las áreas litorales," in Salinas de Andalucía (Seville, Sp.: Consejería de Medio Ambiente, 2004). 7. Antonio Álvarez Rojas, Darío Bernal Casasola, Alicia Arévalo González, "La factoría de salazones de Baelo Claudia," Cuadernos de prehistoria y arqueología 25, no. 2 (1999). 8. Guillermo Vázquez Consuegra, Arquitecturas de Autor (Pamplona, Sp.: T6 Ediciones, 2009).

9. "Baelo Claudia alcanza su récord histórico con 151.600 visitantes en 2015," Europa Press, January 26, 2016.

10. "El «spa salino» de Chiclana, un baño curativo para piernas y brazos," $A B C$ de Sevilla, July 26, 2013.

11. Teresa Almendros, "Ángel León se hace con la explotación del Molino de Mareas durante 30 años," Diario de Cádiz, March 21, 2015.

12. Pedro Espinosa, "Ecologistas se opone al proyecto de Ángel León," El País, December 29, 2014

13. Arancha Muñoz Criado, Parque Lineal de San Pedro, COAMU Catálogos (Murcia, Sp.: COAMU - Colegio Oficial de Arquitectos de la Región de Murcia, 2004): 12.

14. See note 5 .

15. Miguel Ángel Sánchez Sánchez, and Gustavo Ballesteros Pelegrin, "Los paisajes de las salinas de San Pedro del Pinatar," Gran Tour, Revista de Investigaciones Turísticas 11, 2015.

16. Juan Manuel Barragán Muñoz, Ana Macías Bedoya, "Las salinas andaluzas en la planificación y gestión integradas de las áreas litorales," in Salinas de Andalucía (Seville, Sp.: Consejería de Medio Ambiente, 2004).

17. See note 6.

18. Rafael Alberti, Prosas Encontradas 1924-1942 (Madrid: Ayuso, 1970).

\section{Credits}

Figures 1 and 3-6: photos by the Author.

Figure 2: photo by Alberto Di Lolli.

Figure 7: diagram by the Author.

Ana Morcillo Pallares is an Assistant Professor in architecture at the University of Michigan Taubman College of Architecture and Urban Planning, where she was a 2014-2015 Walter B. Sanders fellow. She received her PhD in architecture from the Escuela Técnica Superior de Madrid and her professional degree in architecture from the Escuela Técnica Superior de Valencia (Spain). Her work explores the evolution and revitalization of public space through theoretical debate between citizen demands and municipal regulations in understanding the social, economic, architectural and urban conditions of the collective.

E-mail: anmorcil@umich.edu 